\title{
Screening for Controlled Substance abuse
}

To the Editor:

We would like to commend Manchikanti et al (1) on their elaborate study, Screening for Controlled Substance Use in an Interventional Pain Management Setting, published in the October 2003 issue of Pain Physician. In an area with a paucity of research and understanding, this study provides valuable clinical information.

First, we are pleased that 4 of the 6 criteria developed by us to detect prescription opioid abuse (2) were externally validated by this study in a prospective manner. One of the two criteria developed by us, which could not be validated in this study, was "exaggeration of pain." However "pain behavior" in this study was significantly associated with abuse. If "pain behavior" is considered as another expression of "exaggeration of pain," then 5 of our 6 criteria have been validated.

Some criteria, which could be highly associated with abuse, may not be easily detectable in clinical practice. This was confirmed in this study, as the incidence of certain criteria listed below was low including:

- Current investigation or prior conviction for illicit drugs or opiates

- Current or prior use of illicit drugs and denial

- Needle tracks, skin abscesses, inflamed nares, perforation of nasal septum

- Altering prescriptions

Another interesting observation was that only $5 \%$ in the abuse group admitted to prior or current illicit drug use, whereas in previous studies by Manchikanti et al (3-6), significant proportions of patients were shown to abuse controlled substances and were also using illicit drugs. Further, in a recent study by Katz et al (7), of the 122 patients they studied, only $22 \%$ had behavioral issues in contrast to $29 \%$ who had positive urine toxicology screen. They further showed that percentage of patients with positive urine toxicology alone was $21 \%$; whereas behavioral issues alone was only $14 \%$; in contrast both positive urine toxicology and behavioral issues were present in only $8 \%$ of the patients.

We also agree with the authors that "pseudoaddiction" may not be applicable in the chronic pain population. Although the possibility of "pseudoaddiction" can be entertained in this setting, "abuse" should be ruled out first.

Lastly, one of the three criteria in the assessment tool in this study was "current or prior intentional doctor shopping." This further emphasizes the need for the National All Schedules Prescription Electronic Reporting (NASPER).

This assessment tool's strength lies in its simplicity and ease of application. Additionally it is not based on subjective responses of patients.

\section{REFERENCES}

1. Manchikanti L, Singh V, Damron KS et al. Screening for controlled substance abuse in interventional pain management settings: Evaluation of an assessment tool.
Pain Physician 2003; 6:425-433.

2. Atluri S, Sudarshan G. A screening tool to detect the risk of prescription opioid abuse among patients with chronic nonmalignant pain. Pain Physician 2002; 5 : 447-448.

3. Manchikanti L, Pampati V, Damron K et al. Prevalence of illicit drug use in patients without controlled substance abuse in interventional pain management. Pain Physician 2003; 6:173-178.

4. Manchikanti L, Pampati V, Damron K, Fellows B, Barnhill R, Beyer C. Prevalence of opioid abuse in interventional pain medicine practice settings: A randomized clinical evaluation. Pain Physician 2001; 4: 358-365.

5. Manchikanti L, Pampati V, Damron K, Beyer C, Barnhill R, Fellows B. Prevalence of prescription drug abuse and dependency in patients with chronic pain in western Kentucky. J KY Med Assoc 2003; 101:329-335.

6. Manchikanti L, Damron K, Beyer C, Pampati V. A comparative evaluation of illicit drug use in patients with or without controlled substance abuse in interventional pain management. Pain Physician 2003; 6:281-285.

7. Katz NP, Sherburne S, Beach M et al. Behavioral monitoring and urine toxicology testing in patients receiving long-term opioid therapy. Anesth Analg 2003; 97:1097-1002.

Sairam Atluri, MD

Tri-State Pain Management Institute 10160 Meadowknoll Dr.

Loveland $\mathrm{OH} 45140$

E-mail: atluri_ps@sprynet.com

Gururau Sudarshan, MD

Cincinnati Pain Management 10505 Montgomery Road

Cincinnati OH 45242

E-mail: gsudarshan@cinci.rr.com 